\title{
Questioning the Problematic Nature of School Culture in Elementary Teacher Education
}

Lori T. Meier*

East Tennessee State University

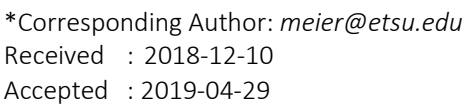

How to cite this paper: Meier, L.T. (2019). Questioning the Problematic Nature of School Culture in Elementary Teacher Education, Journal of Culture and Values in Education, Volume 2 (1), 34-44.

\section{Abstract}

This paper explores the role of school culture as embodied by elementary teacher preparation in relationship to humanizing pedagogies. Further, it explores how the school culture of elementary teacher preparation can be experienced as an oppressive force towards identity formation and humanization for students who position themselves outside of the conventional norms of the field and traditionally accepted membership criteria. A brief play in three acts shares anecdotes from students who consider themselves in the margins of elementary teacher preparation with recommendations for teacher educators seeking to humanize the elementary teacher preparation curriculum and experience to be inclusive of all students.

Keywords: Elementary Education, Humanization, Identity, Pre-service Teacher Education

\section{Introduction}

Fellow educators - are we not lost? Do we know where we are, remember where we have been, or foresee where we are going? -Dwayne Huebner (1999, pg. 231)

This essay seeks to serve as both commentary and plea to elementary teacher educators and gatekeepers. It first asks us to consider that the culture of elementary teacher education, while characteristically an honorable and moral vocation, can indeed function as an oppressive and marginalizing force in the development, humanization, and growth of aspiring new teachers. Second, it entreats those who work in teacher education to foster, seek out, and support those individuals who find themselves at the diverse, intellectual, creative, and aesthetic margins of traditional elementary teacher preparation norms. To its detriment, the cultural disenfranchisement of these seemingly unconventional new teachers limits the richness of curriculum possibilities, pedagogy, and identity development towards humanization (Freire, 2000). As Danielewicz (2001) suggests and this essay endeavors to make a central thesis, "Teaching is a moral act. A teacher education program should recognize, celebrate, and honor 
the intentions of prospective teachers who so often feel committed to improving the lives of others, alleviating social inequalities, and eradicating discrimination" (p. 194).

I begin with a brief contextual explanation describing how this came to be a point of inquiry for myself as a teacher educator and continue with an exploration into the intersection of school culture, teacher education, and humanization. I share dissonant voices in the form of a play with reference to observations and anecdotes informally shared with me from elementary teacher education students and conclude with suggestions for ways we might consider a different, more humanized approach to individuality in elementary teacher education.

\section{Context}

As an elementary teacher educator for over a decade in a university-based teacher preparation program, I've witnessed a disappointing phenomenon. Nearly each year, one or two students pursuing coursework and clinical experience in elementary teacher education are (intentional or unintentionally) encouraged by various gatekeepers or processes in teacher education to consider their "suitability" in relationship to the cultural expectations of elementary school teaching. I encounter these discussions typically during our undergraduate social studies methods course time together where we concurrently embed beginning theory about democratic classrooms, culturally responsive pedagogy, and teaching towards transformative social studies learning. I position myself as a faculty ally and often, over coffee, we find time to discuss the dissonance that they are experiencing as soon-to-be educators. I'm also able to share my own experiences of teaching outside the margins of what is often considered the "norm" in elementary education. Make no mistake; these are intelligent, capable, sophisticated future teachers with a desire for transformative elementary school classrooms. However, the culture of elementary teacher education programs and the culture of elementary schooling often deliver subtle (or not so subtle) messages to them that their identity, individuality, gender, aesthetic, interest in thoughtful intellectual dialogue, and curious aspirations for democratic, humanized spaces are not a good fit for the elementary classroom. Gatekeepers in teacher education, clinical placements, and elementary schools can powerfully, yet quietly lay out the cultural "rules and boundaries" that the "good teachers" are expected to embody - and sadly, these are often contrary to those that encourage individuality, humanization, and democratic teaching and learning for all.

\section{School Culture \& Teacher Education}

Sarason (1995) proposed that schools are highly differentiated, yet complex subcultures of society. Schools function as miniature societies that operate under similar cultural structures as the society at large. Peterson and Deal (2002) suggested school culture was an underground river of feelings, norms, outlooks, folkways, and values that influence how people go about their daily work, while Bower (1966), succinctly proposed that school culture was 'the way we do things' around here. Despite the distinctions between various stakeholders and spaces of schooling, a general culture of "school" exists and includes patterns of those who have similar values, perceptions, goals, training, technical skills, and expectations (Sarason, 1995). School cultures often demand that participants be socialized to the expected patterns, rules, and 
behavior of the cultural group. Schein (1985) argued that culture is, "the deeper level of basic assumptions and beliefs that are shared by members of an organization, that operate unconsciously, and the define in a basis 'taken-for-granted' fashion an organization's view of itself and its environment" (p. 6). Sarason (1996) shares a parallel sentiment, "if your life's work is in schools, you have been socialized to see them in certain ways and to become insensitive to many things you take for granted and, therefore never examine" (p. 334).

For the purposes of this discussion, I suggest that these definitions for school culture can be utilized and modified to explore and problematize the culture of elementary teacher preparation, what we call here teacher education, since it employs a similar set of attributes and expectations, gatekeepers, and social norms similar to schools. Indeed then, schools and teacher education are positioned as small social organisms (Waller, 1932) and are compromised of social agents and players. As new entrants to the culture are prepared and positioned for future membership, processes of socialization to the field, such as specialized schooling and mediated entry, are enacted to encourage assimilation (Lortie, 1975). As such, school culture and the culture of teacher education can contribute to both liberating and oppressive experiences.

\section{Humanizing Pedagogy}

Humanization in the tradition of Paulo Friere is, "the process of becoming more fully human as social, historical, thinking, communicating, transformative, creative persons who participate in and with the world" (Salazar, 2013, p. 126). In the same way, curriculum and pedagogy that embodies humanistic qualities allows us to more fully realize democratic visions of education and citizenship. Gutman (1987) suggests, "A democratic theory of education focuses on what might be called 'conscious social reproduction' - the ways in which citizens are or should be empowered to influence the education that in turn shapes the political values, attitudes, and modes of behavior of future citizens" (p. 14).

Humanism and humanizing pedagogy have been offered as counter narratives (Salazar, 2013) to the dehumanizing practices rampant in the high-stake standardization of public schools. Further, "it is the moral duty of educators to understand and enact humanizing pedagogy that is grounded in theory, possible in practice, and shaped by the realities of students' and teachers' lives" (Salazar, 2013, p. 142). Lafer (2014) builds on this thought, "The humane thing, I have come to realize, is the thing and the humanity of the actions I take as an educator is and always has been the criterion against which I have made determinations of right and wrong actions as a teacher" (p. 6).

\section{Dissonant Student Voices: A Play in Three Acts}

I present a play in three acts in an effort to informally, yet hopefully share nuanced commentary about elementary teacher education belonging and identity as generated by its very own students. Using multiple characters, the thinking shared here is an amalgamation of fused thoughts, numerous direct quotes, lived experiences, and frustrations as shared by students and former students with me for the purposes of this essay. Our elementary teacher education 
program is mostly comprised of White, female students. However, both male and female voices are represented in this play. Elementary teacher education frequently appears to be a homogenous landscape but there are subtle commonalities amongst the teachers who believe themselves to be in the "margins" of teacher education in my experience, I find that often they have a deep interest in the humanities and fine arts and several note previous majors in the arts and sciences before opting into elementary education. As a whole, they are nurturing thinkers who are at times misperceived as being too reserved, too loud, too quiet, or just a bit unusual. Often they are healthy skeptics of the pied pipers of education and factory-like processes they see in schools and teacher education. Nearly all of the students I've encountered who have found themselves feeling a bit out of place are intellectually rigorous and divergent individuals who see education as a socially just, liberating space (Giroux, 1988).

Act One (Setting: A local coffee house, five friends gather Max, Emily, Rachel, Ted, and Elizabeth)

Max: I've determined that our coffee group should be called the Island of Misfit Teachers and we are located just off the coast of the World of Elementary Education, you know just like in Rudolph.

Emily: I'm in. I watched several friends today share perfectly organized backpacks and monogrammed pencil cases, and meanwhile I know I have a Dungeons and Dragons binder in mine. I don't mind being different, but I do wonder how I'll continue to fit in.

Rachel: Agreed! Just this week I felt inadequate in class with my 'crappy handwriting' and inability to draw - apparently these are "useful" expected tools for activities for elementary teachers.

Elizabeth: Well, at least you weren't referred to as 'Sid the Sloth' by a teacher when you completed your math lesson. Can't teaching be a deliberate, calm, and reflective experience too?

Ted: You've got to be kidding me - they told you that? As "constructive criticism" about your teaching?

Elizabeth: Yes, sir. That's exactly what she told me. And that maybe I wasn't a good fit for elementary kids.

Max: Last semester, I was supervised by two different people, both women, who suggested that I might do better in a high school or collegiate environment. I don't mean to sound negative, but I worry that it perpetuates this unsaid expectation of elementary teachers. I worry that it could hinder employers from potential teachers who would bring beauty, depth, and diversity to the world of elementary education but don't fit the typical mold.

Elizabeth: I wonder if this is because, people that evaluate us, they expect personality traits that are extroverted in nature - you know boisterous, bubbly, hyper-performative, Ron Clark 
types. I was a theatre minor, so I definitely have a performance streak but I'm also thoughtful and introverted and I'm not loud in the classroom.

\section{Act Two (the conversation continues)}

Max: I mean no offense here, but I do feel that feminine aesthetics dominate the elementary classroom. I know it is a female dominated profession, but there's something about this specific type of femininity. It is a type that includes monogrammed possessions - you know, Yeti coffee mugs, bags, shirts - along with essential oils, cursive fonts, zig-zagged and polka-dotted tenant flags for classroom décor and so on. Of course none of these things are inherently feminine, but they have been determined so by western gender expectations. Meanwhile, I have faced the assumption from others that as a male teacher I will not have it "as together" as my female coworkers and that my classroom will be sloppier and I will not be as nurturing, which is definitely frustrating!

Ted: I absolutely understand what you are saying. I'm thinking about that time one professor told me and another male student, all two of us, in front of the whole class, that we would never be successful elementary teachers. Because, being men we did not have the inherent compassionate characteristics that our female classmates would have. I can't wait to prove this professor wrong.

Emily: But what about different kinds of women in the classroom? I worry more for females who do not fit the "hyper-feminine" teacher norm. I worry that we will be slighted of opportunities or discouraged simply because we do not fit the mold as females in education. I already know of instances where this is already happened.

Max: My concern is this - I can't help but feel that prospective elementary teachers generally value aesthetic over best practice. It seems that there is more thought put into classroom style, theme, and management than educational theory and pedagogy. And there definitely seems to be widespread distrust about educational theory and theorists from some students and teachers in teacher education.

\section{Act Three (the conversation concludes for the afternoon)}

Rachel: I feel like the majority of students in our classes have very similar views. I thought this today about religion. As someone who is not religious, I feel ostracized and I'm somewhat afraid to express my opinion on certain subjects. I know we talked about funds of knowledge in class and the connection to literacy but almost every student expressed that they feel church was critically important to kids' literacy and I'm fearful to express that I never went to church. I'm worried if my colleagues will be fully open and inclusive to kids that do not go to church.

Emily: Being surrounded by people and teachers who often do not share my views or interests, I worry that my views might end up getting me judged. Still, on the other hand, I fear that I'll hear something that I find offensive but won't have the confidence to say anything, I definitely feel like I'm not part of the group, and I'm quite okay with that. 
Max: It's challenging to imagine a different future if I'm being honest. My hope for elementary education is that it becomes a profession for all sorts of people. I have found a small niche of people on Twitter who are educational oddballs. Teachers who love heavy-metal, have long hair, tattoos and goatees. People who care deeply for how we teach kids and knows their way around different teaching practices. I hope that the elementary world becomes more welcoming to artists, actors, musicians, Muslims, Jews, atheists, agnostics, LGBTQ+ people, people of color, thinkers, skeptics, railfans, Whovians, Potterheads, philosophy nerds, etc. There's room for everyone, and our children's lives will be made much richer by their presence.

\section{Towards a More Humanized Pedagogy of Elementary Teacher Education}

When the culture of elementary teacher education is made problematic we can explore how culture can, and often does, limit the development of and dehumanizes new teachers as individuals and thinkers. For that reason, a new kind of teacher education praxis is needed for the humanization of both educators and future educators. A humanizing pedagogy is necessary for the distinct transformative and liberating change we hope to see in everyday elementary classrooms and schools. Method is always connected to theory (Gee, 2000).

As I consider this I am reminded that teacher education includes many stakeholders and gatekeepers. Faculty, temporary faculty, accrediting bodies, clinical supervisors, retired teachers, mentor teachers, districts, school administrators, and others each can play a role in contributing to a more or less human experience in teacher ed. Faculty in teacher education carry a significant responsibility in this matter. Gatekeepers in all areas of education, according to Thornton (2005), make educational decisions in their classrooms, "the place where it matters the most". The process of gatekeeping (Thornton, 2005) then functions to implore the new teacher and teacher educator to be the curricular decision makers (gatekeepers) inside their own classrooms in contrast to top-down reform mandates, standards-driven instruction, and competency based teacher education that would otherwise drive instruction and educational purposes. As Thornton notes, "educators' purposes, and how they act on them, matter" ( $p$. 104).

Changing the nature and function of teacher education is a complex and complicated undertaking that I do not attempt to overlook with my plea for a more humane understanding of preparing elementary teachers. Balderrama (2001) suggests that, "As teachers become dehumanized and disconnected from their work, so do their teaching practices" (p. 261). Decades of research into teacher education have outlined various practices and possibilities that we might incorporate into teacher education programs to change outcomes and yet, teacher education continues to suffer from an identity crisis of purpose. One identity being one that leans toward a technical-rational training ground for the standardized, factory-like "audit cultures" (Taubman, 2009) while a competing more idealistic identity seeks to envision the promises of integrated, holistic education that includes socio-cultural understandings that we hope lead to transformative practice. Indeed in both settings, we can do better. 


\section{Pursue Shared Dialogical Relationships in Teacher Education}

Freire (2000) suggests that the humanistic, revolutionary educator cannot wait for the oppressed to become aware of their dehumanization at the hands of banking methodology and resolve to valiantly struggle for their own liberation. Instead, the teacher educator must engage students towards critical thinking about their humanization. Teacher educators should be willing and capable of, "challenging simplistic views of, and approaches to, teaching as telling or the transmission of information" (Loughran, 2006, p. 14). I suggest connections here to Freire's idea regarding the fear of freedom whereby new teachers (perhaps all new teachers due to positioning of power in teacher education, but especially for those who find themselves a bit outside the margins of teacher education) would suffer at the hands of "prescriptions" enacted by teacher educators. Unable to imagine an autonomous freedom from the oppressor both the oppressed and the oppressor are dehumanized (Freire, 2000). Freire (2005) further speaks to this, "it is for this very reason that authoritarian administrations, even those that call themselves progressives, try through various means to instill in teachers a fear of freedom. When teachers become fearful, they begin to internalize the dominator's shadow and the authoritarian ideology of the administration. These teachers are no longer alone with their students because the force of the punitive and threatening dominant ideology comes between them" (p. 16). Teacher educators and related gatekeepers must authentically seek to develop and maintain dialogical relationships with students who are considering becoming teachers. Freire (2000) argues that dialogue, "requires an intense faith in humankind, faith in their power to make and remake, to create and re-create, faith in their vocation to be more fully human" (p. 90). With this in mind, authentic dialogical relationships between educators and students must be built on love of life and people, humility, faith, trust, hope, and critical thinking that leads towards transformation together (Freire, 2000).

For teacher education, this is a challenging task. It would require that all parts of the milieu work together towards a common articulated mission. Knowledge of critical pedagogy, humanization, conscientization strategies, and dialogical relationships should be shared vocabulary not only by the academic faculty who may have experience with this scholarship in their content areas; but also embodied within the practices and discourse of clinical supervisors, adjuncts, and mentors. Moreover, students must be brought alongside to assist in the coconstruction of dialogical spaces. Pedagogy must be fashioned with, not for, the oppressed and evolutionary leadership must embody co-intentional education in an effort to recreate this new knowledge (Freire, 2000).

Given that we know that elementary programs often consist of classrooms of compliance, consensus, agreement, and conformity (Segall, 2002) students of teacher education programs should be provided opportunities to challenge and disrupt norms of socialized behavior in elementary education and imagine how schooling experiences and elementary teacher identities could alternatively be created. For this to occur, perhaps we might problematize with our students, early in their programs, how elementary teacher education itself might contribute to their colonization through oppressive discourse and messaging about their identity and individuality. In his 'love letter' to teachers, Ayers (2010) suggests that, "All the 
pressures of schooling push teachers to act as clerks and functionaries -- interchangeable parts in a vast and gleaming and highly rationalized production line. To teach with a heart and a brain -- to see education as a deeply humanizing enterprise, to teach toward opening infinite possibilities for your students -- requires courage" (p. 153).

\section{The Personal is Pedagogical}

Central to the scripted narratives of those who felt misunderstood at moments in their teacher education experiences is the understanding that identity and individuality matters to them. For students, having the capacity to know oneself is essential when one learns about teaching (Loughran, 2006). Further, "the nature of self-image and issues of identity formation matter" (Loughran, 2006, p. 110) if learning about teaching is going to factor into long-term student teacher development. For teacher educators, we carry a considerable responsibility to help foster this (Loughran, 2006) in beginning teachers. Instead of requiring that our soon-to be new teachers be mindlessly socialized into images and behavioral stereotypes of what an elementary teacher must or should be we instead choose a path that encourages the humanity in each student; a path that acknowledges their distinct identity, interests, capabilities, experiences, and promise. In efforts to disrupt the cultural reproduction that is so visible in elementary teacher education and elementary schools, we should take care to foster the development of those students that perhaps think of themselves as located outside traditional norms in ways that do not make them feel marginal at all. Indeed, these are the exact students that schools and children need in their lives to promote humanization.

Freire (1998) reminds us, "as a teacher, I must open myself to the world of these students with whom I share my pedagogical adventure. I must become acquainted with their way of being in the world" (p. 122). To do this, teacher educators might consider making room for nonjudgmental, participatory spaces where the personal lives, identities, personalities, and individualities of new teachers can be honored and encouraged. Incorporating arts-based methods like collage (McDermott, 2002) allow an exploration of meaning-making through aesthetics and educational inquiry about the self. Students are able to share personal lived experiences and pedagogical ideals that help them to consider the diverse kinds of teachers that they might be. In a similar capacity, Diamond, Borho, and Petrasek (1999) outline a postmodern structure that I believe could be utilized in elementary teacher preparation that asks educators to explore and share identity through the development of a personal canon. In this exercise, similar to the creation of literary canons, a teacher develops a collection of authors, books, plays, poems, narratives, creative works, film, music, imagery, etc. that imbue their perspectives and individual pursuits of meaning (Diamond, Borho, \& Petrasek, 1999). The authority that new teachers experience in selecting these touchstone 'bits and pieces' (deeply connected to who they are and who they are becoming) allows students to become, "more conscious of how and what they knew' (p. 116). I suspect that this type of arts-based inquiry would also allow teacher educators to share in their own processes of identity meaning-making as individuals and educators in a collaborative, humanistic way. As bell hooks (1994) challenges us, "professors who embrace the challenge of self-actualization will be better able to create pedagogical practices that engage students, providing them with ways of knowing that enhance their capacity to live fully and deeply" (p. 22). As teachers and scholars whose mission it is to 
teach about teaching and learning, I am hopeful that we can provide intentional spaces for new educators to think about their own humanity and individuality as they see their lives and selves positively manifested in elementary classrooms. 


\section{References}

Ayers, W. (2010). To teach: The journey of a teacher. New York, NY: Teachers College Press.

Balderrama, M. (2001). The (mis)preparation of teachers in the Proposition 227 era: Humanizing teacher roles and their practice. Urban Review, 33, 255-267.

Bower, M. (1966). Will to manage. New York, NY: McGraw Hill.

Danielewicz, J. (2001). Teaching selves: Identity, pedagogy, and teacher education. Albany, NY: State University of New York Press.

Diamond, C., Borho, B., \& Petrasek, P. (1999). "Finding the pieces" of a personal canon: Teachers as "Free artists of themselves". In C.T.P. Diamond \& C.A. Mullen (Eds.), The postmodern educator: Arts-based inquiries and teacher development (pp. 95-120). New York: Peter Lang.

Freire, P. (1998). Pedagogy of freedom: Ethics, democracy, and civic courage. Oxford, England: Rowan \& Littlefield Publishers.

Freire, P. (2000). Pedagogy of the oppressed. New York, NY: Continuum International.

Freire, P. (2005). Teachers as Cultural Workers: Letter to those who dare teach. Boulder, CO: Westview Press.

Gee, J. (2000). Identity as an analytic lens for research in education. Review of Research in Education, 25(1), 99-125.

Giroux, H. (1988). Teachers as transformative intellectuals: Toward a critical pedagogy of learning. New York: Bergin \& Garvey.

Gutman, A. (1987). Democratic education. Princeton, NJ: Princeton University Press.

hooks, b. (1994). Teaching to transgress. New York, NY: Routledge.

Huebner, D. E. (1999). The lure of the transcendent. Mahwah, NJ: Lawrence Erlbaum Associates.

Lafer, S. (2014). Democratic deisgn for the humanization of education. Journal of Ethnic and Cultural Studies, 1(1), 6-12.

Lortie, D. (1975). Schoolteacher. Chicago, IL: University of Chicago Press.

Loughran, J. (2006). Developing a pedagogy of teacher education. New York: Routledge. 
McDermott, M. (2002). Collaging pre-service teacher identity. Teacher Education Quarterly, 29(4), 53-67.

Peterson, K. D. \& Deal, T. E. (2002). The shaping school culture fieldbook (1 ed.). San Francisco, CA: Jossey-Bass.

Salazar, M. (2013). A humanizing pedagogy: Reinventing the principles and practice of education as a journey toward liberation. Review of Research in Education, 37(1), 121-148.

Sarason, S. (1996). Re-visiting the culture of the school and the problem of change. New York, NY: Teachers College Press.

Sarason, S. (1995). School change: The personal development of a point of view. New York, NY: Teachers College Press.

Schein, E. H. (1985). Organizational culture and leadership. San Francisco: Jossey Bass.

Seagall, A. (2002). Disturbing practice: Reading teacher education as text. New York, NY: Peter Lang.

Taubman, P. (2009). Teaching by numbers: Deconstructing the discourse of standards and accountability in education. New York: Routledge.

Thornton, S. J. (2005). Teaching social studies that matters: Curriculum for active learning. New York, NY: Teachers College Press.

Waller, W. (1932). The sociology of teaching. New York, NY: Wiley. 